\title{
Assessment of Soil Organic Carbon in Tropical Agroforests in the Churiya Range of Makawanpur, Nepal
}

\author{
Lilu Kumari Magar, Gandhiv Kafle $(D)$, and Pradeep Aryal \\ Faculty of Forestry, Agriculture and Forestry University, Makawanpur, Hetauda, Nepal \\ Correspondence should be addressed to Gandhiv Kafle; gandhivkafle@gmail.com
}

Received 30 July 2020; Revised 29 September 2020; Accepted 5 October 2020; Published 15 October 2020

Academic Editor: Manoj Kumar Solanki

Copyright (C) 2020 Lilu Kumari Magar et al. This is an open access article distributed under the Creative Commons Attribution License, which permits unrestricted use, distribution, and reproduction in any medium, provided the original work is properly cited.

\begin{abstract}
This paper reports the findings of a research study conducted in three tropical agroforestry systems in the Makawanpur district of Nepal, to quantify the spatial and vertical distribution of soil organic carbon in $30 \mathrm{~cm}$ soil profile depth in agrisilviculture, home garden, and silvopasture. The three agroforestry systems represent tropical agroforests of Nepal. It was found that the soil had $24.91 \mathrm{t} /$ ha soil organic carbon in $30 \mathrm{~cm}$ soil profile in 2018 , with $2.1 \%$ soil organic matter concentration in average. Bulk density was found increasing with an increase in soil depth. The soil organic carbon was not found significantly different across different agroforestry systems. Looking into the values of stocks of soil organic carbon, it is concluded that the tropical agroforests have played a role in global climate change mitigation by storing considerable amounts of soil organic carbon and the storage capacity can further be increased. Involvement of farmers in the management of tropical agroforests cannot be ignored in the process of climate change mitigation.
\end{abstract}

\section{Introduction}

The interaction between climate change and the global carbon cycle is an important aspect of the global environment changes [1]. Soil is the largest pool of terrestrial organic carbon in the biosphere, storing more carbon than contained in plants and the atmosphere combined [2] and a relatively stable pool of various organic and inorganic carbon fractions. The soil organic carbon stock has a unique function in mitigating climate change as a key component of the biosphere carbon cycle. Changes in soil organic stock can have a considerable effect on atmospheric carbon dioxide concentration, contributing to global warming. There is a worldwide consensus that climate change is a spreading threat in this century. Nepal is among the most vulnerable countries to climate change [3]. Trees on the farm have a vital role in mitigating the effects of climate change. Both soils and trees on the farmlands are significant media for carbon storage [4]. The area currently under agroforestry worldwide is 1,023 million hectares [5]. A recent assessment by the Government of Nepal shows $40.36 \%$ forest and $4.38 \%$ other woodlands of the total area of the country. The other wooded land represents the trees on farmland and fallow land with trees [6].

The land use of Nepal is changing day by day [7]. The implementation of agroforestry is less costly and more effective than other approaches [8]. Agroforestry is an agroecological praxis that contributes to the sustainable intensification of food production while providing a number of additional benefits to society. Agroforestry can make significant contributions to provision of soil-mediated ecosystem services in the humid and subhumid tropics [9]. Agroforestry systems have indirect positive effects on carbon sequestration because they reduce harvesting pressure on natural forests. Incorporating trees and shrubs in food crop systems help in addressing food insecurity, increasing carbon dioxide sequestration, and reducing the vulnerability of agricultural systems. Agroecosystems also contribute to the mitigation of climate change and are being an adaptation strategy for the farmers [10]. Agroforestry is one of the strategies of REDD+ to reduce carbon emissions, enhance forest carbon stocks, and improve the supply of forest 
products by promoting agroforestry [11]. The potential of agroforestry systems to accumulate carbon is estimated to be 0.29-15.21 Mg ha ${ }^{-1}$ year $^{-1}$ [12]. Field data on soil carbon pools are needed for the estimation of sources and sinks of greenhouse gases at the national level to be reported to the UNFCCC, to predict the carbon sequestration potential of the nation's forest resources and to promote nutrient balance for enhanced productivity of the ecosystems. In this context, this research was conducted to investigate how soil organic carbon in the soil profile varied under different agroforestry systems in the Churiya Range, Makawanpur, Nepal.

\section{Materials and Methods}

2.1. Research Site. The research was carried out in Laisiran and Bangdirang of Raksirang Rural Municipality of Makawanpur District in the midhill region of Nepal (Figure 1). Makawanpur district lies between $27^{\circ} 21^{\prime}$ to $27^{\circ} 40^{\prime} \mathrm{N}$ latitude and $84^{\circ} 41^{\prime}$ to $84^{\circ} 35^{\prime} \mathrm{E}$ longitude and is $34 \mathrm{~km}$ south of Kathmandu. The meteorological data from Hetauda and Manahari stations of Makawanpur district during 1985-2015 periods (31 years) show that the mean annual temperature for thirty-one years is found to be $23.0^{\circ} \mathrm{C}$. The rainfall shows the decreasing trend of total annual precipitation in Hetauda, Makawanpur, at the rate of $5.6607 \mathrm{~mm}$ per year. Annual rainfall fluctuates regularly in last 31 years. The highest rainfall recorded is about $3323.1 \mathrm{~mm}$ in the year 2002 and the least amount rainfall, i.e., $1626.2 \mathrm{~mm}$, was recorded in the year 2012. Even though it fluctuated regularly throughout 31 years, the rainfall has decreased a bit [13]. Three major agroforestry systems: agrisilviculture system, home garden, and silvopasture system, were selected for data collection. Nepalese soils are most often developed on micaceous parent materials such as phyllites, schists, quartzite, and granites, and the texture is normally loam and sandy loam in the hilly region [14]. The textural class of agricultural soil of Makawanpur district ranges from sandy loam to silt loam [15].

2.2. Data Collection. Ten pits were randomly dug in three major agroforestry systems: agrisilviculture system, home garden, and silvopasture system. Soil samples were collected from 0 to $10 \mathrm{~cm}, 11$ to $20 \mathrm{~cm}$, and 21 to $30 \mathrm{~cm}$ from each pit using a cylindrical soil corer of $10 \mathrm{~cm}$ length and $3.45 \mathrm{~cm}$ radius. So, a total of 30 soil samples were collected from each agroforestry system, with total 120 soil samples in all agroforestry systems. One additional soil sample (undisturbed soil sample) from each soil depth was collected using the soil core sampler to determine the bulk density. Each sample was bagged, labelled, and transported to laboratory for analysis. The soil sample collection and laboratory analysis processes were performed as in [16].

2.3. Laboratory Analysis of Soil Samples. Soil bulk density was determined using the soil core sampler having a diameter of $5.7 \mathrm{~cm}$ [17]. The soil organic carbon concentration was determined by dry combustion of oven-dry soil samples at $900^{\circ} \mathrm{C}$ [18]. The percentage of soil organic matter was converted to soil organic carbon by multiplying with 0.58 , as soil organic matter is assumed to contain $58 \%$ of organic carbon. Total nitrogen (TN) was determined by the Kjeldahl digestion-distillation method [19]. Soil pH of a composite sample (of all soil layers and soil pits) from each agroforest was determined using a $\mathrm{pH}$ probe with a glass-calomel electrode (Suntronics pH electrode, Suntronics, India), keeping $1: 1$ soil: water ratio [20]:

Bulk density of soil = oven-dry weight of soil in grams/ volume of soil in cubic centimetres.

Soil organic carbon in ton per hectare $=$ organic carbon content $(\%) \times$ soil bulk density $\times$ depth of soil layer.

The significanct difference of soil organic carbon was tested using ANOVA at a 5\% level of significance. SPSS software (IBM SPSS Statistics, IBM Corporation, version 20) was used for statistical analysis of the data.

\section{Results and Discussion}

Local people practised three major agroforestry systems, namely, agrisilviculture, home garden, and silvopasture in the study area. These systems are characterised in Table 1.

Average bulk density in agroforests up to $30 \mathrm{~cm}$ depths was found to be $1.19 \mathrm{gm} / \mathrm{cm}^{3}$ close to the value 1.28 gram per cubic centimetre [21], 1.17 gram per cubic centimetre [22], and 1.18 gram per cubic centimetre found by Ghimpre et al. [22] in two Shorea robusta-dominated tropical forests of Nepal. The average bulk density of soils in different depths $0-10 \mathrm{~cm}, 11-20 \mathrm{~cm}$, and $21-30 \mathrm{~cm}$ were found to be 0.375 gram per cubic centimetre, 0.38 gram per cubic centimetre, and 0.39 gram per cubic centimetre, respectively (Table 2).

The average soil $\mathrm{pH}$ in $30 \mathrm{~cm}$ soil depth of the agroforests was found to be 6.6. The $\mathrm{pH}$ value was closer to the values reported by Kafle (2019) [21] (5.3), Sigdel [23] (5.90-6.42), Karki [24] (6.4-7.1), and Singh and Singh [25] (6.7-6.8). The soil $\mathrm{pH}$ was found near to the neutral value suitable for agricultural production.

The average soil organic carbon in $30 \mathrm{~cm}$ soil depth of the agroforests was found to be $2.1 \%$. There was a gradual decrease in the percentage of soil organic carbon with an increase in soil depth. The order of percentage content of average soil organic carbon in $30 \mathrm{~cm}$ soil depth was silvopasture $(2.73 \%)>$ home garden $(1.87 \%)>$ agrisilviculture (1.69\%) (Table 3). These values were close to the values reported by Paudel and Sah [26] (1.74\% $\pm 0.31 \%$ soil organic carbon in the mixed Shorea robusta forest). This may be due to a similar physiographical range, climatic condition, and soil sampling. Schwab et al. [27] found $1.6 \%$ mean soil organic matter content in agroforests, Neupane and Thapa [28] found an organic matter content of 1.5-2.3\%, Desbiez et al. [29] reported 2-3\%, and Carson [14] assessed 0.5-3\% with an average under $1 \%$. The higher average soil organic carbon percentage in soil samples in our results may be caused by the higher organic matter content of the agroforestry systems in the study area.

The average stock of soil organic carbon in $30 \mathrm{~cm}$ soil depth in the agroforests was found to be 24.91 ton/ha. These values were close to the values reported by Baral et al. [30] who estimated $23.48 \mathrm{t} /$ ha soil organic carbon in agricultural land. The order of stocks of average soil organic carbon in 


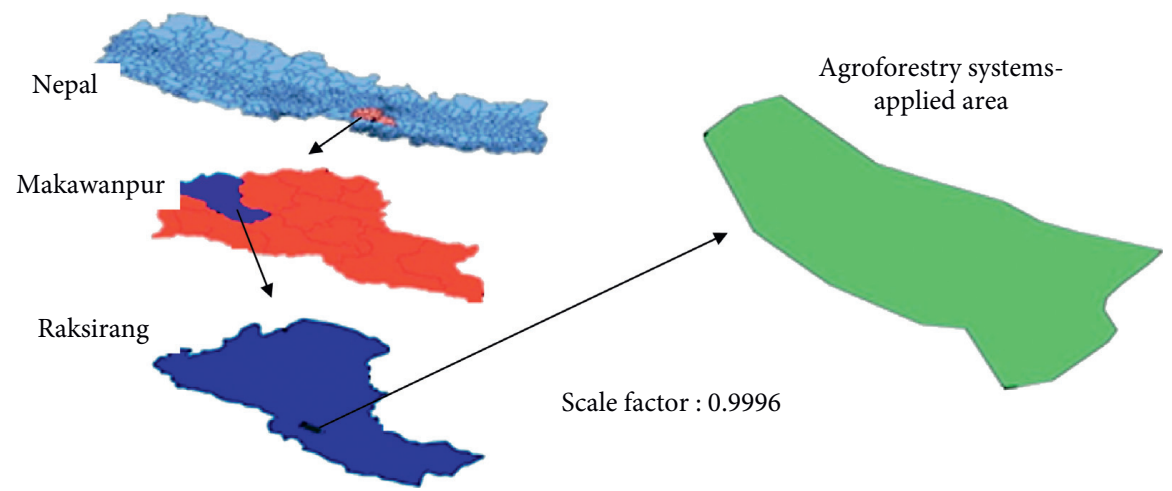

FIGURE 1: Map showing the agroforestry system-applied area in Raksirang Rural Municipality, Makawanpur, Nepal.

TABLE 1: Characteristics of agroforestry systems in the study area.

\begin{tabular}{|c|c|c|}
\hline Agroforestry system & Arrangement of components & Species \\
\hline \multicolumn{3}{|c|}{ (1) Agrisilviculture (crops and trees including shrubs) } \\
\hline & $\begin{array}{c}\text { Cereal crops and lentils grown on terraced rainfed } \\
\text { cultivated land (bari) under widely spaced } \\
\text { naturallygrowing fodder tree species }\end{array}$ & $\begin{array}{l}\text { Cereal crops: Zea mays, Triticum aestivum, and } \\
\text { Panicum miliaceum } \\
\text { Trees: Dalbergia sissoo, Artocarpus lakoocha, and } \\
\text { Bombax ceiba }\end{array}$ \\
\hline \multicolumn{3}{|c|}{ (2) Home garden (cereal crops, trees, fruits, house, and domestic animals) } \\
\hline & & $\begin{array}{l}\text { Tree species: Ficus semicordata, Melia azedarach, } \\
\text { Bauhinia purpurea, and Artocarpus lakoocha }\end{array}$ \\
\hline & $\begin{array}{l}\text { Multipurpose trees, fodder trees, fruit trees, nontimber } \\
\text { forest products }\end{array}$ & $\begin{array}{c}\text { Fruit species: Citrus limon, Musa paradisiaca, Ananas } \\
\text { comosus, Carica papaya, and Mangifera indica } \\
\text { Nontimber forest products: Curcuma domestica and } \\
\text { Zingiber officinale }\end{array}$ \\
\hline \multicolumn{3}{|c|}{ (3) Silvopasture (pasture/animals and trees) } \\
\hline $\begin{array}{l}\text { Fodder trees: forage } \\
\text { grasses and animals }\end{array}$ & $\begin{array}{l}\text { Forage grasses grown on terraced bari under naturally } \\
\text { growing fodder trees; goat, cow, and buffalo in cut and } \\
\text { carry system }\end{array}$ & $\begin{array}{c}\text { Trees/fodder species: Garuga pinnata, Schima wallichii, } \\
\text { Madhuca indica, Bombax ceiba, Ficus hispida, Leucaena } \\
\text { leucocephala, and Bauhinia purpurea } \\
\text { Grasses: Thysanolaena maxima, Saccharum } \\
\text { spontaneum, and Eulaliopsis binate }\end{array}$ \\
\hline
\end{tabular}

TABLe 2: Average bulk density $\left(\mathrm{gm} / \mathrm{cm}^{3}\right)$ at various depths and agroforestry systems.

\begin{tabular}{lcccc}
\hline \multirow{2}{*}{ Agroforestry system } & \multicolumn{3}{c}{ Soil depth $(\mathrm{cm})$} & Total average \\
& $0-10$ & $11-20$ & $21-30$ & $\left(\mathrm{gm} / \mathrm{cm}^{3}\right)$ \\
\hline Agrisilviculture & 1.06 & 1.16 & 1.17 & 1.13 \\
Home garden & 1.29 & 1.33 & 1.34 & 1.32 \\
Silvopasture & 1.03 & 1.13 & 1.23 & 1.13 \\
\hline
\end{tabular}

$30 \mathrm{~cm}$ soil depth was Silvopasture $>$ home garden$>$ agrisilviculture (Table 4). The amount of soil organic carbon in agroforestry systems differs with regions, agroforestry systems, and soil depths [31].

There was a gradual decrease in the stocks of soil organic carbon with an increase in soil depth in the agroforests. The higher organic carbon percentage in the top layer may be due to rapid decomposition of litter in a favorable environment. Soils with rich organic carbon levels generally indicate high fertility, and therefore, it is important to
TABle 3: Average soil organic carbon percentage at various depths and agroforestry systems.

\begin{tabular}{lcccc}
\hline \multirow{2}{*}{ Agroforestry system } & \multicolumn{3}{c}{ Soil depth $(\mathrm{cm})$} & Total average \\
& $0-10$ & $11-20$ & $21-30$ & \% carbon \\
\hline Agrisilviculture & 2.02 & 1.68 & 1.37 & 1.69 \\
Home garden & 2.38 & 1.69 & 1.53 & 1.87 \\
Silvopasture & 3.09 & 2.74 & 2.38 & 2.73 \\
\hline
\end{tabular}

maintain its optimum level that requires a careful land use and management practices [32]. Gautam and Mandal [33] also reported a decreasing trend of soil organic carbon with increased depths of soil in a tropical moist forest in eastern Nepal. Similar findings on the decline of stocks of soil organic carbon with the increase in soil depth were reported by Pandey et al. [34] in S. robusta-dominated forests of hills and Terai regions of Nepal; Ghimre et al. [22] in the S. robustadominated tropical community forest of Nepal, and Kafle [21] in a tropical community forest of Nepal. Song et al. [35] 
TABle 4: Total soil organic carbon stock (ton/ha) at various depths and agroforestry systems.

\begin{tabular}{lcccc}
\hline Agroforestry system & \multicolumn{3}{c}{ Soil depth $(\mathrm{cm})$} & Total soil organic carbon stock (ton/ha) \\
& $0-10$ & $11-20$ & $21-30$ & 19.55 \\
Agrisilviculture & 7.70 & 6.30 & 5.54 & 24.94 \\
Home garden & 10.74 & 7.29 & 6.91 & 30.25 \\
Silvopasture & 11.62 & 10.38 & 8.24 & \\
\hline
\end{tabular}

also reported that the concentrations of soil organic carbon decreased with depth, and the greatest concentration was in the $0-10 \mathrm{~cm}$ topsoil in selected forests of China.

\section{Conclusion}

Results of this research have shown evidence of tropical agroforests playing a role in the storage of soil organic carbon in Nepal. The average bulk density of soils in tropical agroforests was found to be $1.15 \mathrm{gm} / \mathrm{cm}^{3}$ in $30 \mathrm{~cm}$ soil profile depth. The average soil organic carbon of the soil was found to be 24.91 tons/ha. The soil organic carbon was found decreasing with increased soil depths. Bulk density of the soil was found increasing with increased soil depths. It is found that the soil of tropical agroforests had a high potentiality of storage of organic carbon and is playing a role in global climate change mitigation. The topsoil contained higher amounts of SOC, so the agroforest management practices should consider retaining organic matter on the floors of agroforests.

\section{Data Availability}

The data used to support the findings of this study may be released upon application to the first author, who can be contacted at lkmagar@afu.edu.np.

\section{Conflicts of Interest}

The authors declare that they have no conflicts of interest.

\section{Authors' Contributions}

LKM designed the study, PA collected the data, and GK wrote the manuscript together with LKM.

\section{Acknowledgments}

The authors hereby express their deepest acknowledgements and heartfelt gratitude to the local community and local government of Rakshirang Municipality for their cooperation and significant contribution for the successful completion of this research. The authors are also highly grateful to Regional Soil Test Laboratory, Hetauda, for providing the laboratory facilities to analyse the samples.

\section{References}

[1] IPCC, Climate Change 2007 Synthesis Report: Summary for Policymakers, IPCC, Geneva, Switzerland, 2007, http:// pure.iiasa.ac.at.
[2] W. M. Post and K. C. Kwon, "Soil carbon sequestration and land-use change: processes and potential," Global Change Biology, vol. 6, no. 3, pp. 317-327, 2000.

[3] ICIMOD, Melting Glacier of Himalayan and Nepal's Initial National Communication Report, ICIMOD, Patan, Nepal, 2017.

[4] H. Agevi, R. Onwonga, S. Kuyah, and M. Tsingalia, "Carbon stocks and stock changes in agroforestry practices: a review," Tropical and Subtropical Agroecosystems, vol. 20, pp. 101-109, 2017.

[5] A. K. Osei, "Estimating carbon stocks in tree biomass and soils under rotational woodlots and ngitili systems in Northwestern Tanzania," M. Sc. thesis, Department of Soil Science, University of Saskatchewan, Saskatoon, Canada, 2014.

[6] DFRS, State of Nepal's Forest. Forest Resource Assessment (FRA) Nepal, Department of Forest Research and Survey (DFRS), Kathmandu, Nepal, 2015.

[7] B. Paudel, Y. L. Zhyang, L. I. Shi-Cheng, L. Lin-Shan, W. Xue, and N. R. Khanal, "Review of studies on land use and land cover change in Nepal," Journal of Mountain Sciences, vol. 13, no. 4, pp. 663-660, 2016.

[8] ICIMOD, Policy and Institutions in Adaptation to Climate Change: Case Study on Tree Crop Diversity in China, Nepal, and Pakistan, ICIMOD, Patan, Nepal, 2013.

[9] M. N. Muchane, G. W. Sileshi, S. Gripenberg, M. Jonsson, L. Pumariño, and E. Barrios, "Agroforestry boosts soil health in the humid and sub-humid tropics: a meta-analysis," $A g$ riculture, Ecosystems \& Environment, vol. 295, Article ID 106899, 2020.

[10] K. R. Gautam, "Carbon sequestration in agroforestry and annual cropping system in inner terai, Central Nepal," M. Sc. thesis, Agriculture University of Norway, Stavanger, Norway, 2002.

[11] MoFE, "Nepal national REDD + strategy (2018-2022), ministry of forests and environment, government of Nepal," 2018.

[12] S. K. Dhyani, A. Ram, R. Newaj, A. K. Handa, and I. Dev, "Agroforestry for carbon sequestration in tropical India," in Carbon Management in Tropical and Sub-tropical Terrestrial Systems, pp. 313-331, Springer, Singapore, Singapore, 2020.

[13] B. Subedi, R. A. Mandal, and D. L. Adhikari, "Climate variability, disasters and their impacts assessment in Manahari, rural municipality of Makwanpur, Nepal," Journal of Historical Archaeology \& Anthropological Sciences, vol. 4, no. 6, pp. 201-210, 2019.

[14] B. Carson, The Land, the Farmer, and the Future, International Centre for Integrated Mountain Development (ICIMOD), Patan, Nepal, 1992.

[15] R. M. Bajracharya, B. K. Sitaula, S. Sharma, and A. Jeng, "Soil quality in the Nepalese context," An Analytical Review International Journal of Ecology and Environmental Sciences, vol. 33, no. 2-3, pp. 143-158, 2007.

[16] ANSAB and Forest Carbon Stock Measurement, Guidelines for Measuring Carbon Stocks in Community-Managed Forests, ANSAB, Kathmandu, Nepal, 2010. 
[17] G. R. Blake and K. H. Harte, "Bulk density," in Methods of Soil Analysis Part 1. Physical and Mineralogical Methods-Agronomy Monograph, A. Klute, Ed., pp. 363-375, American Society of Agronomy-Soil Science Society of America, Madison, WI, USA, 2nd edition, 1986

[18] D. W. Nelson and L. E. Sommers, "Total carbon, organic carbon and organic matter," in Methods of Soil Analysis Part 2. Chemical and Microbiological Properties, A. L. Page, R. M. Miller, and D. R. Keeney, Eds., pp. 539-580, American Society of Agronomy, Madison, WI, USA, 2nd edition, 1982.

[19] J. M. Bremner and C. S. Mulvaney, "Nitrogen-Total 1," in Methods of Soil Analysis. Part 2. Chemical and Microbiological Properties, American Society of Agronomy, Soil Science Society of America, Madison, WI, USA, 1982.

[20] E. O. McLean and C. S. Mulvaney, "Soil pH and lime require," Methods of Soil Analysis. Part 2. Chemical and Microbiological Properties, (Methodsofsoilan2), 1982.

[21] G. Kafle, "Vertical distribution of soil organic carbon and nitrogen in a tropical co mmunity forest of Nepal," International Journal of Forestry Research, vol. 2019, Article ID 3087570, 2019.

[22] P. Ghimire, G. Kafle, and B. Bhatta, "Carbon stocks in Shorea robusta and Pinus roxburghii forests in Makawanpur district of Nepal," Journal of AFU, vol. 2, pp. 241-248, 2018.

[23] E. R. Sigdel, Physico-chemical properties of Soil in Royal Chitwan National Park, Thesis, Kathmandu: Central Department of Botany, Tribhuvan University, Kirtipur, Nepal 1994.

[24] S. Karki, Ecological study of riverine forest in Koshi Tappu Wildife Reserve (KTWR), Thesis, Kathmandu: Central Department of Botany, Tribhuvan University, Kirtipur, Nepal 1999.

[25] S. P. Singh and J. S. Singh, "Structure and function of the forest ecosystems of central Himalaya: implications for management," in Environmental Regeneration in Himalaya: Concepts and Strategies, J. S. Singh, Ed., Central Himalayan Environment Association and Gyanodaya Prakashan, Nainital, India, 1985.

[26] S. Paudel and J. P. Sah, "Physiochemical characteristics of soil in tropical sal (Shorea robusta Gaertn.) forests in Eastern Nepal," Himalayan Journal of Sciences, vol. 1, no. 2, pp. 107-110, 2003.

[27] N. Schwab, U. Schickhoff, and E. Fischer, "Transition to agroforestry significantly improves soil quality: a case study in the central mid-hills of Nepal," Agriculture, Ecosystems \& Environment, vol. 205, pp. 57-69, 2015.

[28] R. P. Neupane and G. B. Thapa, "Impact of agroforestry intervention on soil fertility and farm income under the subsistence farming system of the middle hills, Nepal," Agriculture, Ecosystems \& Environment, vol. 84, no. 2, pp. 157-167, 2001.

[29] A. Desbiez, R. Matthews, B. Tripathi, and J. Ellis-Jones, "Perceptions and assessment of soil fertility by farmers in the mid-hills of Nepal," Agriculture, Ecosystems \& Environment, vol. 103, no. 1, pp. 191-206, 2004.

[30] S. Baral, R. Malla, S. Khanal, and R. Shakya, "Trees on farms: diversity, carbon pool and contribution to rural livelihoods in Kanchanpur District of Nepal," Banko Janakari, vol. 23, no. 1, pp. 3-11, 2013.

[31] M. Negash and M. Starr, "Biomass and soil carbon stocks of indigenous agroforestry systems on the south-eastern rift valley escarpment, Ethiopia," Plant and Soil, vol. 393, pp. 95-107, 2013.
[32] N. Dahal and R. M. Bajracharya, "Prospects of soil organic carbon sequestration: implications for Nepal's mountain agriculture," Journal of Forest and Livelihood, vol. 9, no. 1, pp. 45-56, 2013.

[33] T. P. Gautam and T. N. Mandal, "Soil characteristics in moist tropical forest of Sunsari district, Nepal," Nepal Journal of Science and Technology, vol. 14, no. 1, pp. 35-40, 2013.

[34] H. P. Pandey and M. Bhusal, "A comparative study on carbon stock in Sal (Shorea robusta) forest in two different ecological regions of Nepal," Banko Janakari, vol. 26, no. 1, pp. 24-31, 2016.

[35] Z. Song, K. McGrouther, and H. Wang, "Occurrence, turnover and carbon sequestration potential of Phytoliths in terrestrial ecosystems," Earth-Science Reviews, vol. 158, pp. 19-30, 2016. 